\title{
A General Outlook of the Importance of the English Language in the World Today
}

\author{
PhD Ervin Balla \\ University Aleksandër Moisiu Durrës, Albania \\ Email: ervin_balla@yahoo.com
}

\section{Doi:10.5901/ajis.2016.v5n3s1p499}

\begin{abstract}
No study can be started today about the use of the English language and its learning in the albanian universitites without bringing up first the great importance that this language has in all the world. From 4000 to 5000 languages spoken today in the world today English is most spread language. According to Broughton it is the most spread language of a great number of states and besides being the official language of United Nation and the language used by NATO, it is the official language of the international airborne, and non offically it is the first language of sport, music etc. Also today in Albania in all types of education it remains the most learned and used language. Today sudents in Albania are learning this language for different type of purposes. They plan to start schools abroad, or they plan to find a job where the English language is required, or simply they would like to read or listen songs in English. Taking into cosideration these and other purposes it was decided to write this article.
\end{abstract}

Keywords: Teaching and learning English, importance of studying English, the most spread language.

\section{English Today in the World}

We cannot start a study about the use of English language and its teaching in Albanian universities without bringing up the great importance that is gaining every day this language in the whole world. From 5000 up to 6000 languages spoken today in the world, the English is the most spread language. According to Broughton it is the most spread language in a number of states. Besides being the language of the United Nations and the language used by NATO, it is the official language of international airborne, and not officially it is the first language of sport, music etc. As matter of fact more than 60 per cent of the programs of radio are transmitted in English language and it is also the language of the 70 per cent of $e$ mail exchanges in the whole world.

English language is not only a beautiful and simple language in use but it is also a simple language in grammar (the lack of a complicated system of grammar rules). It is also true the fact that in this language exists a simpler form of conjugation of verbs (compared to Albanian or other Latin languages) which makes it simpler to be remembered. There are also in use some other cases of simplified English such as that created by C.G. Odgen and experimented successfully in other parts of the world. His idea is using approximately 850 words to express the minimum of ideas and opinions in English language in order to be understood and also for practical reasons.

The modern English is a practical language that has absorbed too many words from other languages especially Latin languages. It is a Germanic language, but because the influence of the Latin languages especially in the beginning of our era and due to the roman conquest, Norman expansion in the land of England, trade and several other reasons, English language was enriched with many Latin origin words adopted to the English rules of phonology and grammar. As we can see from the statistics the English language has borrowed from many other languages. According to Joseph $\mathrm{M}$ Williams in his work "Origins of English language" this language has the origin of words mainly from Latin. 


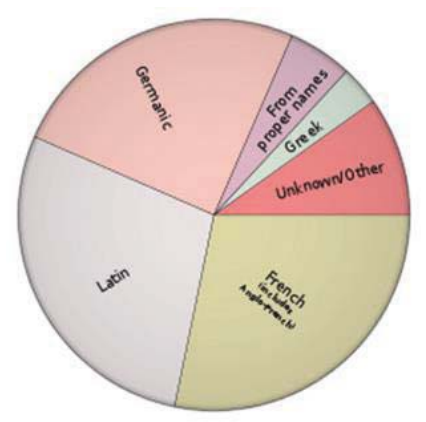

Chart 1: About the origin of English language

Starting from what we said about the origin of the English language very frequently the beginner students of this language who do not have too much knowledge in this language sometimes find it not very hard to understand texts in English because they may have knowledge in Latin origin languages (especially in Italian or French). Even though they may find it difficult to read the texts especially when these texts are difficult, they very frequently may have a general idea about the content of the texts, due to similarities in words between the English and other languages that they may know, making in this aspect much easier and enjoyable the process of teaching and learning.

It is foreseen that about the 2050 about half of the world will be fluent in English language. (According to The Economist "The triumph of English language). According to Westwood, earlier the reasons to learn a foreign language were not clearly defined. The recognition of a foreign language was considered a sign of well education. Today English has more practical reasons to be learned. The practical and ease in use of this language according to the studies conducted with students and generally admitted are as follow:

1) Not having dense and difficult grammar rules especially with the conjugation of the verbs (different from the Latin languages or Albanian language)

2) The use of Latin letters has made easier its usage by many Latin speaking countries (Russian or Chinese for example)

3) Various conquers and colonization of the countries made by England which today are powerful countries such as Canada, Australia, America etc, but this influence is for the countries conquered by England and cannot explain the importance that this language has gained in the countries where English is spoken as a foreign language and were not invaded or colonized by England

4) The importance that this language has gained especially after the second world war when England and America were placed amongst the winning countries

5) The place in the global economy of the countries which speak English as the first language (such as England, America, Canada, Australia) etc.

Another important reason that why students would like to study the English language is also the fact that global distribution of British literature, has anticipated the distribution of English language. In English language are written many world masterpieces of literature as Volter has claimed: "It is one of the languages that owns the greatest number of brilliant masterpieces". But learning English is not casual and of course it requires commitment by students and teachers of foreign language, as Murcia stresses out that learning a foreign language requires true actions. Also the dominant role of English urges students to learn this language. Clearly a good mastering of this language is a proof of social and economical improvement for all the students, and a good knowledge of English mean a lot to students. As it was seen students really have good reasons to learn English and as Broughton says: "English is not a property of all the English speaking countries but it belongs to the whole world".

It is not difficult to find out everywhere you go the first thing that we note as soon as we step into airports, international ports notice boards, tables, warnings posted and the majority of them are written in English. It can be seen that today the role of English in the world is influenced by geographical, historical cultural and political factors. English is the language of media, journals, radio and television. It is also the language of institutions, courts and the language of huge industrial and commercial organisations.

According to Seidlohfer the English language has reached the status of lingua franca and it is not important if we see it as a result of language imperialism or as a conscious choice of students or simply because it was found at the "right place at the right time" the number of people that use English as a foreign language for various purposes in different 
contexts has led Kachru to consider the countries that use English as "places of closed circuits" and England itself can not consider its language as its own property. Another example is the fact that English is the language of international conferences. Also we can see the trend of English learning compared to other languages according to a declaration for the press of Brussels in article of date September 20th 2012.

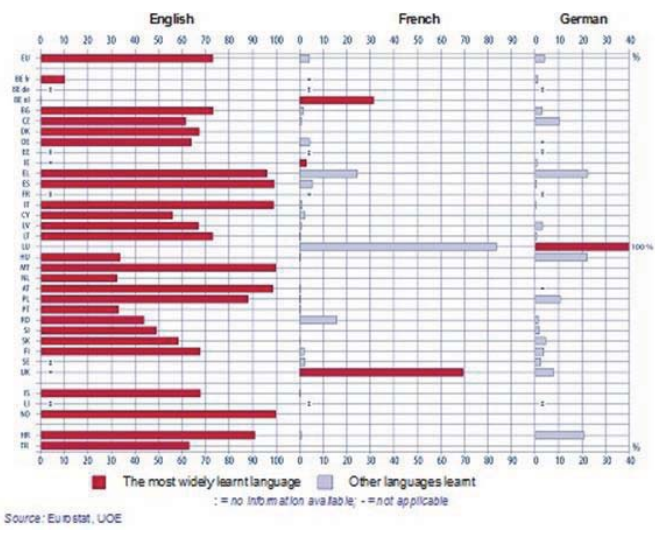

Chart 2: About the learning of English language compared to other languages

\section{English as a Foreign Language or a Second Language}

So far according to Broughton the English has been considered by the countries who speak it as a second language but for the rest of the world English is a foreign language, that means it is a language taught at school but it does not play a prominent role in social and national role. Today has been agreed widely that there are more bilingual of English language than monolingual of English language. Recently it estimated that more than a billion people are learning English in the whole world and according to the British Council 750 million of these students traditionally are considered those students that learn English as a foreign language and about 375 million are those who learn English as a second language. However the majority of students of English today are adding English to their repertoire not to replace their mother tongue but they are learning English along with their mother tongue for pre-specified purposes (Albanian student's case). All the English teachers ask about the purposes of teaching that languages, if they are teaching it as a first or foreign language? According to the international vocabulary of Webster second edition we find these terms found used very frequently. The word foreign derives from the middle English (forein, forene), but also found in old English (foras) and Latin language also meaning an outsider. According to Broughton the distinction between English as a foreign and a second language are not clear cut.

But nevertheless English is a foreign or a second language its teaching is of a great importance. According to a study performed by Liu to the students of an American university confirmed that the fluency in language is required both from students who speak English as a second and foreign language. According to Crystal the English is described as global English for both types of students (those who speak as second language and for those who speak as a foreign language).

The teachers and the lectors of the foreign language may ask what mean "foreign" for colleagues, students and the community in general? Even though someone may contradict the term "foreign" this term is very true if we would take into consideration the way how English is taught in a school in Pattaya Thailand and in a school in Youngstone in Ohio. In Pattaya Thailand the English is taught as a foreign language, meanwhile in Ohio Youngstone it is taught as a foreign language. The contexts of teaching are not the same, not even the teachers and the students are not the same but do these facts change the nature of the language? According to Savignon what may constitute an issue in these cases is the language competence of the students. Is the student a native speaker of English? If not does he consider himself or herself as a bilingual? If so why not? Is it still considered a lack of language competences, or more a lack of faith in communication? According to Broughton students learn English as a foreign language have an option to choose the varieties of the language more than the students who learn it as a second language.

However according to Gradol, English as a foreign language or as a second language is not used simply "as a 
chosen language" because it is the only language shared with another speaker; it is used frequently because culturally it is considered as the appropriate language for a special context of communication. Such a wide use of a language as the use of English language is unprecedented. According to Kashru the English speaker today include those living in countries where English is a first language such as USA, England, Canada, Australia, New Zealand or countries like Bangladesh, India, Nigeria, Philippines and Tanzania which use English as a second language or countries like China, Indonesia, Saudi Arabia and Russia which use English mainly in international context or as a foreign language. Through the conservative calculations the number of non native speakers of English today surpasses the number of native speakers more than 2 to 1 and has a tendency to increase. There are also many varieties of English that some scholars talk about "world Englishes".

At the same time it is seen the need to find out more how the second languages are learnt. In the first sight the meaning of "learning a second language is "transparent" but in fact it requires a careful explanation. In fact in this context "a second" language can be referred to any language that can be learned right after the mother tongue. Also "second language" is not contradictory with "foreign language" and if this language is learned naturally living in a place where this language is spoken or in a classroom through explanation, it is referred normally as "learning the second language". Learning the second language can be defined as a way through which students learn a language different from their mother tongue, in or outside the classroom.

However the distinction between the English as a second language (ESL) and English as a foreign language (EFL) are not clear cut. The place of English in the life of many students if it learnt as a foreign or a second language it is less easy to define than it was years ago. Nevertheless English language that is taught in our universities is guided mainly toward practical aspect, as it was mentioned above and the reasons that the students learn it are mainly to find a better job, to study abroad, to communicate with other communicators of English etc. According to West the non natives of English language learn this language mainly to express their ideas in this language rather than their feelings. To express their emotions normally they use their mother tongue. This is a general rule showing that the words used to express emotions are of a second hand importance for a non native student of English language, as it is seen English is learnt mainly for pragmatic and practical reasons such as the reasons mentioned above.

\section{English Language at the School}

Taking into consideration the above mentioned factors and too many other factors, it can be seen that English language has taken an extraordinary place in communication and its use by millions and millions of people all over the world, its teaching has become a necessity and not an ordinary subject in the process of education in Albanian universities. As a result of that too many countries around the world including Albania are facing an increase of the demand to learn English since the first classes of elementary school, so by taking into consideration the importance of learning the English language it is seen as a necessity the addition of extra English classes, the curricula of English should be enriched and other important factor for learning the English is the submission of students to final exam of English. According to Broughton this has led an addition of English classes into all the schools of the world, more than any other subject so far.

Naturally the subject of the foreign language in schools is becoming of a special importance, this not only regarding the academic aspect but also in the practical aspect of English as a lingua franca, in business different works or in every day communication. In the teaching aspect not only the method used for this purpose plays an important role, but also several other factors need to be taken into consideration. According to Murcia to reach high results in his work the English teacher has to bear in mind a few things which are considered to be important for him in his daily routine.

First, the teacher has to assess the need of the students to learn English. Why would they like to learn English? Secondly the teacher has to assess several other important factors in learning such as the frequency of classes, the size of the classrooms and the number of students attending the classes, the quality of the materials used in the process of teaching (books, syllabuses etc). Based into this factors the teacher may decide what is important for students and what should he explain during the class, or how to make this material in order to meet the students need and what priorities should be important during his classes.

Studying English or other foreign language in Albanian schools starts early, since fifth or in some schools in third or fourth class. But its early study does not correspond to study of English in other countries of European Community where the learning of this language start since three years according to the declaration about learning English in European Community. Even though the knowledge gained in elementary classes are modest, the students feel as necessity to create their normal behaviour in learning this language, where the traditional teaching of this language happens normally with the teacher centred method, where the teacher is the centre and the main provider of information is mostly the main 
teaching activity in the schools of villages and towns. In Albania like other countries who study English as a foreign language the level of students is homogenous where can be found students of different levels of recognition of English starting from elementary level to advance levels.

If the teachers of foreign languages would teach a rare language in Albania such as Chinese or Hungarian very few students would have knowledge about it, and the learning of the language by the students would start from scratch, since none would have knowledge about that language, but since the English language is learnt at the third class and the contact with the language are different for each student, the level of the students who attend our universities is different, so the method used for teaching them would be different. According to Harmer classes of different level of language have their own problems and the teacher has always the responsibility to give an appropriate solution starting from the differentiated work in groups according to their level of knowledge in English, the use of methods according to their level with terms and words appropriate to their age, and to work toward their motivation and stimuli in achieving high results. Also according to Broughton a continuous attempt toward learning the foreign language toward learning the foreign language is much more fruitful than a spontaneous learning. The way of continuous exposure to the language and daily communication makes possible the accomplishment of main purposes since we always bear in mind the fact that we have to deal with groups of various levels of knowledge.

From the point of view "the more someone is exposed to a language the more he learns", the learning of the modern learning in school has also an educational function, and the student that decides to study English has a clear instrumental reason: he would like to visit England, or to be able to communicate with his English speaking friends, or maybe to be able to read books in English, but also other reasons such as finding a job, promotion ${ }^{1}$ etc.

\section{References}

Beare, K. (2010). How many people learn English globally? Retrieved July 6, 2010 from http:/lesl.about.com/od lenglishlearnngresources/fff_esImarket .htm

Broughton G. Brumfit Ch. Flavell R. Hill P. Pincas A. (2003) "Teaching English as a a foreign language" Routledge \& Kegan Paul Ltd Fq 109

Broughton G. Brumfit Ch. Flavell R. Hill P. Pincas A. (2003) "Teaching English as a a foreign language"Routledge fq 7

Broughton G. et.al (1981) 'Teaching English as a foreign language, fq 7, Routledge \& Kegan Paul Ltd fq 6

Bruksel ne artikullin e dates 20 shtator 2012. (Children in Europe start learning foreign languages at an increasingly early age).

Celce Murcia M. "Teaching English as a second or foreign language" Thomson learning, fq 10

Crystal D. (1997) "English as a global language" Cambridge, Cambridge University Press

Ellis R. (2003) "Second language acquisition" Oxford University Press, fq 9

Graddol, D. (1997). The future of English? London: The British Council, fq 12

Graddol, D. (2006). English next: Why global English may mean the end of "English as a Foreign Language". London: British Council

Harmer J (1998) "How to teach English" fq 10, Longman

Kachru, B. B. (1985). Standards, codification and sociolinguistic realism: The English language in the Outer Circle. In R. Quirk \& H. G. Widdowson (Eds.),English in the world: Teaching and learning the language and literatures (pp. 11-30). Cambridge: Cambridge University Press.

Liu D. (1999) "Training non native TESOL students, Challenge for TESOL, teacher education in the west"Edited by B Grahine

McKay, S. L. (2002). Teaching English as an international language: Rethinking goals and approaches. Oxford: Oxford University Press Montgomery S. (2013) "Does science need a global language?" The University of Chicago Press, fq 18

Roth.G. (2001) "Teaching very young children", Richmond Publishing, fq 5

Savingnon S.J (1997) "Communicative language teaching (CLT) for the tëenty first century" Neë Heaven, Yale University press fq 26 Sipas deklarates per shtyp te Komisionit Europian Bruksel, 20 shtator 2012 IP-12-990_EN

West, M. (1953) "A General Service word List", Longman.

${ }^{1}$ Broughton G. Brumfit Ch. Flavell R. Hill P. Pincas A. (2003) "Teaching English as a a foreign language" Routledge \& Kegan Paul Ltd Fq 7 Northrup. D (2013) "How English became the global language" fq 123, Palgrave Macmillan

Clece-Murcia M. (2001) "Teaching English as a second or a foreign language" Thomson learning fq 144

Seidlhofer, B. (2001). "Closing a conceptual gap: The case for a description of English as a lingua franca". International Journal of Applied Linguistics, 11(2), 133-158. 